\title{
Audit Market Dynamics: Effects on Audit Quality
}

\author{
Emma Sophie de Groot ${ }^{1}$
}

\begin{abstract}
This study researches the effects of market share dynamics on audit quality in the U.S. audit market from fiscal years 2005 to 2013 . Thus far, the audit market has only been researched in terms of static market share mobility. This research reflects competition more accurately by using market structure dynamics to map the U.S. audit market. The study finds that there is in fact a rather high degree of market share instability within the audit market, which indicates a high degree of competition. Moreover, two out of three models show a significant influence of market share instability on proxies for audit quality. The directions of these effects indicate that market share instability has a positive effect on audit quality. The paper therefore concludes that audit market share dynamics have a positive effect on audit quality.
\end{abstract}

Keywords: audit quality; market dynamics; audit market

\section{Introduction}

Regulators are increasingly concerned that audit market concentration may harm audit quality, as dominance by Big- $\mathrm{N}$ firms reduces competition and therefore, the incentive to provide high quality audits (DeFond \& Zhang, 2014). The United States Treasury (2008), for example, has expressed concern regarding the market dominance by the Big 4, as they feel it might reduce audit quality due to reduced competition. In an attempt to increase auditor independence and audit quality, the European Union has recently introduced a new revision to the 8th EU Directive. One of the new regulations is that all companies in the European Union have to oblige to a mandatory audit firm rotation at least every 10 years (European Commission, 2016). The United States, however, has not introduced regulation of the same scope yet.

Since the main purpose of an audit is to foster trust in the quality of reporting (International Auditing and Assurance Standards Board, 2014), it is indeed of the utmost importance that audits are of high quality; it makes sense that regulators are concerned. The questions that arise are not only regarding the current quality of audits, but also which factors influence this quality. Prior research (e.g. Francis, Michas \& Seavey, 2012; DeFond \& Zhang, 2014) has shown that one of the many variables that have an effect on audit quality is competition within the audit market. Market structures are analysed in order to measure competition, which can be done in two ways: static and dynamic. Research has been done to determine static market structures (e.g. Boone, Khurana \& Raman, 2012; Francis et al., 2012; Newton, Wang \& Wilkins, 2013), but no one has yet examined dynamic market structures in the market for audit services and its influence on audit quality. That is what this research sets out to do.

In order to do so, audit quality and its attributes will be clarified first, followed by an overview of theory and prior literature regarding market structures and audit quality. Next, the research question and hypothesis will be developed, followed by the research design and sample selection. Then, the results of the analysis will be presented and interpreted. Last, the discussion and conclusion will

\footnotetext{
${ }^{1}$ Emma Sophie de Groot received a bachelor's degree in International Business at Maastricht University in 2017. At the moment she is undertaking a master's in Accountancy and a master's in Human Decision Science at Maastricht University. Contact: es.degroot@student.maastrichtuniversity.nl
} 
summarize the research, compare the findings to prior literature and explain the implications of this study and its limitations.

\section{Background}

Before proceeding and examining what affects audit quality, it is important to define the concept and identify its attributes. However, audit quality is much debated and there is little consensus about how to define audit quality (Knechel, Krishnan, Pevzner, Shefchik \& Velury, 2012). One often-used definition the definition by DeAngelo (1981): audit quality is "the market assessed joint probability that a given auditor will both discover a breach in a client's accounting system, and report the breach." The probability that an auditor will discover a breach depends on, for example, the auditor's capabilities and the audit procedures, while the conditional probability of reporting a breach depends on the auditor's independence.

Regarding the quality attributes the International Auditing and Assurance Standards Board (IAASB, 2014) states that audit quality encompasses inputs, processes, outputs, interactions and contextual factors. The most important input factor is the auditor and his or her values, ethics, attitudes, knowledge, skills, and experience. Concerning the process, quality audits are said to be performed in a rigorous manner, in accordance with laws, regulations and standards. The primary output is considered to be a useful and timely audit report containing the auditor's opinion. Moreover, quality audits require proper interaction between auditors and other stakeholders. Lastly, the context of the processes and interactions has an influence on the audit quality. Context factors include, but are not limited to, corporate governance, audit regulation, cultural aspects and information systems.

Now that the concept of audit quality and its attributes are clarified, factors that influence it need to be identified. Looking at previous literature about audit quality, Francis (2011) has provided an overview of the units of analysis frequently used. He summarizes that there are six units of analysis that affect audit quality: audit inputs, audit processes, accounting firms, audit industry and markets, institutions, and economic consequences of audit outcomes. These units of analysis are paired with possible research topics as identified by Francis (2011) in Table 1 to clarify what they entail. The framework helps to better understand the variety of drivers of audit quality. Furthermore, this overview provides the opportunity to classify research and therefore, to observe which areas require more research.

Table 1: Units of analysis in audit research (Francis, 2011)

\begin{tabular}{ll}
\hline Units of analysis & Potential research topics \\
\hline Audit inputs & Linkage between internal control systems and \\
& financial statement correctness \\
Audit processes & Linkage between audit hours and financial \\
& reporting quality \\
Linkage between auditor compensation and & incentives and behaviour \\
Accounting firms & $\begin{array}{l}\text { Role of the audit industry structure in audit } \\
\text { quality }\end{array}$ \\
Audit industry and Audit markets & $\begin{array}{l}\text { Effect of a certain legal system on auditor } \\
\text { incentives } \\
\text { Institutions }\end{array}$ \\
Economic consequences of audit outcomes & $\begin{array}{l}\text { Market responses to information in an audit } \\
\text { report }\end{array}$ \\
\hline
\end{tabular}

\section{$108 \mid \begin{aligned} & \text { Marble } \\ & \text { Research } \\ & \text { Papers }\end{aligned}$}


Collectively, audit firms constitute an industry, and industrial organization literature has shown that industry structure, one of the units of analysis, can indeed influence factors such as price and quality (e.g. Pepall, Richards \& Norman, 2008; Tirole, 1988). The audit industry level of analysis, as identified by Francis (2011), could encompass industry concentration, scale economies and market share mobility. Francis (2011) concludes, among other things, that the effect that audit market structures have on audit quality is highly underrepresented in current auditing research. The next sections will provide an overview of the theory about market structures and the more recent research that has been conducted into the auditing industry structure and its effects on audit quality.

A common line of thought in industrial organization theory is that the degree of seller concentration affects price and quality (Tirole, 1988). Higher concentration is expected to lead to lower quality, as firms gain market power relative to clients. Because of this increase in power, there is less incentive to provide high quality services, which could be concerning for the audit industry (Ciconte, Knechel \& Schelleman, 2015). Nonetheless, it is not certain that this relationship is valid in a dynamic setting such as the audit market.

Boone et al. (2012) examined the effect of audit market concentration on audit quality within local U.S. audit markets. The study finds evidence consistent with the view that increased market concentration leads to increased auditor tolerance for earnings management. In other words, they find that audit quality goes down with increased auditor concentration. Francis et al. (2012) found similar results when they researched the effect of audit market concentration on the quality of audited earnings in 42 countries. They found that the audit quality was lower in countries where there was a high concentration within the Big 4 group. Therefore, the researchers suggest that policymakers should be cautious for an individual Big 4 firm to dominate the market, as this decreases audit quality.

However, Newton et al. (2013) studied the effects of auditor concentration in the U.S. and found that higher auditor competition leads to increased restatements. These findings suggest that audit concentration is positively related to audit quality. Kallapur, Sankaraguruswamy and Zang (2010) found similar results when they examined how audit market concentration affects audit quality as proxied by accruals in the U.S. audit market. The authors conclude that existing levels of concentration do not negatively affect audit quality, and that policymakers should not be concerned about this matter as concentrated audit markets improve audit quality.

While quite some studies (e.g. Francis et al., 2012; Newton et al., 2013), have been conducted in the field of auditing industry structures, prior research thus far has focused on a static approach to the market. There are, however, multiple reasons to favour a dynamic approach to determine market structures (Buijink, Maijoor \& Meuwissen, 1998). Firstly, research has shown that there is no relation between static measures and dynamic measures of market structure. In fact, concentration measures hide the effects of dynamic processes in markets (Davies \& Geroski, 1997). This implies that the basis on which research has been conducted and on which regulatory decisions have been made in the past does not accurately represent the process of competition within the market. Secondly, the industrial organization literature has been using market share instability to measure firm rivalry for a long time (e.g. Eckard 1987; Sandler, 1988). Finally, it has been argued that while stable market shares may indicate collusion, unstable shares are inconsistent with effective collusion (Schmalensee, 1989). Thus, as the stability or instability of market shares is not evident in static approaches to market structures, it is impossible to tell whether there is collusion or competition in a market when using static approaches. Therefore, Buijink et al. (1998) conclude that dynamic market share mobility describes competition in 
audit markets more accurately than static seller concentration. Thus, while static market concentration might stay the same, there may be intense competition for clients among audit firms that can only be revealed using a dynamic approach. In theory, this means there could still be a high degree competition within the market to ensure high audit quality, as there is a high degree of intra-firm market share transfers, while static market shares remain constant.

Another limitation of previous research that becomes evident when analysing it is that most, especially older, studies use a headcount measure of clients to measure market concentration. This means that researchers use the number of clients of an audit firm to measure its market share. Instead, it would be more accurate to use the audit-fee income to measure an auditor's market share. This is the case because markets should be analysed in terms of factors that fit the business model of the industry (Farris, Bendle, Pfeifer \& Reibstein, 2010). For the audit industry, the business model aims to deliver an audit product: the audit opinion. This delivery could be measured in terms of units or income. However, no two audit opinions require the same amount of time or effort from an auditor, which makes audit-fee income the most accurate measure of the market structure. The reason this has not been used often thus far is probably that this data has been less readily available and the data-gathering costs have been larger for this type of data, especially in the past; it has only been mandatory to report audit fees in the U.S. since 2000, and regulations are similar in many other countries.

The goal of this research is therefore to first determine the market structure dynamics in the entire U.S. audit market in terms of audit fees, after which the effects these dynamics have on audit quality will be determined. In doing so, a field of research that is underrepresented to date will be explored: audit industry structure and its influence on audit quality. In order to determine the relationship between the two, regressions will be performed to test the link between market structure dynamics and proxies for audit quality. One of the implications of the research could be that it becomes clearer whether regulations such as the European Union's mandatory audit firm rotation could actually have a positive effect on audit quality, as such regulations increase market dynamics.

\title{
3. Hypothesis development
}

This research will explore audit market dynamics and audit quality. The research question is: "What is the relationship between audit market dynamics and audit quality?" One sub-question that is studied is: "What is the degree of audit market dynamics compared to static market share turnover?"

As described, evidence regarding the influence of audit market concentration on audit quality is ambiguous. However, as this research sets out to study the effects of audit market dynamics, it reflects the competition in a market more accurately than static market share measures. As competition is believed to have a positive effect on quality in markets (Tirole, 1988), a positive relationship between market share instability and audit quality is expected. The hypothesis that follows is:

\section{$H_{1}$ : There is a positive relationship between audit market competition and audit quality}

\author{
$110 \begin{aligned} & \text { Marble } \\ & \text { Research } \\ & \text { Papers }\end{aligned}$
}




\section{Research design and sample}

The sample period of this research is 2004-2014, using data from the Compustat North America database as well as the Audit Analytics database. This time frame was chosen because it only became mandatory to report audit fees from 2000 onward, and the databases are not complete until 2004. Moreover, the databases are not completely updated beyond fiscal year 2014 yet. Compustat North America supplies general client information, while Audit Analytics provides information on auditor change data, audit fees, restatements and audit opinions. From these databases, a sample of all U.S. auditing firms with clients in the United States was drawn. Excluded from the sample are clients operating in the financial services industry, as characteristics of firms in this industry differ significantly from other firms. After excluding observations with missing data on any of the control variables, a sample of 22,014 client-year observations was left. For the regression analysis, fiscal years 2004 and 2014 have to be excluded as these years served as bases for the leading and lagging variables. Due to outliers, additional client-year observations were excluded in the regression analysis. This leaves a sample of 17,555 clientyear observations for the analysis of models (1) and (2). For model (3), observations without available data on the audit opinion have to be excluded as well, leaving a sample of 16,317 client-year observations for this analysis. An overview of the sample selection can be found in Table 2 .

Table 2: Sample selection

\begin{tabular}{lc}
\hline & $N$ \\
\hline $\begin{array}{l}\text { Client-year observations after combining Compustat and Audit Analytics without missing } \\
\text { variables 2004-2014 }\end{array}$ & 22,014 \\
Less: Fiscal years 2004 and 2014 & $(4,237)$ \\
Less: Observations with outliers & $(222)$ \\
Sample for audit quality regression analysis (models 1 \& 2) & 17,555 \\
Less: Observations with missing audit opinion & $(1,238)$ \\
Sample for audit quality regression analysis (model 3) & 16,317 \\
\hline
\end{tabular}

\subsection{Dependent variable}

As this research sets out to study the effects of market dynamics on audit quality, the dependent variable of the model should proxy for audit quality. Three different models are used in the analysis: the first model uses abnormal working capital accruals as a dependent variable, while the second model uses restatements as a dependent variable, and the third model uses the type of audit opinion as a dependent variable.

Abnormal working capital accruals were developed as a proxy for audit quality by DeFond and Park (2001). Consistent with prior research, the argument for using abnormal accruals in the model is that higher-quality audits mitigate extreme management decisions, and accruals reflect these decisions. Conceptually, the proxy measures the difference between realized working capital and a proxy for the market's expectations regarding the working capital. The market's expectations are based on the expected level of working capital needed to support the current sales level. Specifically, the proxy is defined as follows: 


$$
A W C A_{t}=W C_{t}-\left[\left(\frac{W C_{t-1}}{S_{t-1}}\right) \times S_{t}\right]
$$

where $A W C A_{t}$ is the abnormal working capital accruals in the current quarter, $W C_{t}$ is the noncash working capital in the current year computed as (current assets - cash and short term investments) (current liabilities - short-term debt), $W C_{t-1}$ is the working capital is in the prior year, $S_{t}$ are the sales in the current year, and $S_{t-1}$ are the sales in the prior year. As high abnormal working capital accruals are not considered to be in line with high earnings quality, a negative relation between AWCA and market share instability would indicate increased audit quality due to the competition.

Restatements are a second well-accepted proxy for audit quality (e.g. Chin \& Chi, 2009; DeFond \& Zhang, 2014; Newton et al., 2013). Accounting restatements correct misstatements in previously issued financial statements, and are a very direct and egregious measure of audit quality with a low measurement error (DeFond \& Zhang, 2014). Thus, as restatements correct previous misstatements, a negative relation between market share instability and restatements would indicate increased audit quality. This dependent variable is an indicator variable which is equal to one if a company restated its financial statements, and zero otherwise. This data is extracted from the Audit Analytics database.

The third model uses the audit opinion as the dependent variable and proxy for audit quality. While it may not be easy to associate any type of opinion with audit quality, DeFond, Raghunandan and Subramanyam (2002) argue that an auditor must be objective and withstand client pressure for a clean opinion when issuing a going-concern opinion. This suggests a relationship between the issuing of a modified going-concern opinion and audit quality. Therefore, a positive relation between market share instability and going-concern opinions, after controlling for other variables that influence the issuance of a modified opinion, would indicate increased audit quality. The opinion variable is equal to one if a company received a going-concern modified audit opinion in the current year, and zero otherwise. The information necessary to determine this variable is extracted from the Audit Analytics database.

\subsection{Test variable}

The test variable, market share instability, measures the dynamic turnover of market share in one fiscal year in audit fees. This variable can be determined for the entire market as well as at the auditor level. Market share instability is computed for the market as a whole in the following manner:

$$
M S I=\frac{\frac{\text { Intrafirm change }}{2}+(\text { Entry }+ \text { Exit })}{M A R K E T}
$$

where MARKET is the size of the entire market measured in total audit fees per fiscal year, intrafirm change is the combination of departures and engagements due to a change in auditor by the client, entry is the listing of a new client firm into the market, and exit is the delisting of a client firm from the market. All components are measured in total audit fees paid. The value of MSI is higher when there is a lot of switching between auditors by clients than when clients stay with the same auditor.

At the auditor level, market share instability is computed as follows:

$$
M S I=\frac{\text { clients engaged }+ \text { clients departed }}{\text { Total clients }}
$$

\footnotetext{
$112 \mid \begin{aligned} & \text { Marble } \\ & \text { Research } \\ & \text { Papers }\end{aligned}$
} 
where MSI is the market share instability of a specific auditor, clients engaged are new clients attracted by the auditor, clients departed are clients that left the auditor, and total clients is the amount of clients audited by the auditor during the fiscal year. All are measured in terms of total audit fees. The value of MSI is higher when an auditor loses and gains a lot of clients than when an auditor retains the same clients.

\subsection{Control variables}

For model (1), prior research (Carey \& Simnett, 2006; DeFond \& Zhang, 2014; Myers, Myers \& Omer, 2003) suggests that loss (LOSS), size (SIZE), leverage (LEVERAGE), sales growth (SALES_GROWTH), operating cash flows scaled by total assets (CFO), an indicator for the type of auditor (BIG4), and industry and year are important variables to include in an analysis with abnormal working capital accruals as a proxy for audit quality. Loss making clients are more likely to manage earnings to improve perception. Size measures the size of the client as the natural logarithm of total assets and is positively associated with earnings quality. Companies with more debt compared to assets (leverage) are more likely to have low earnings quality. Sales growth proxies for company growth, and clients with higher growth tend to report more accruals. Operating cash flows are used because they are negatively related to abnormal accruals. Furthermore, Big 4 audit firms have more resources and better reputations, and are therefore expected to deliver higher audit quality (Newton et al., 2013). Lastly, industry dummies control for the type of industry the client operates in and year dummies control for general changes in audit quality over time. All control variables are defined in the appendix.

For model (2), some different control variables are included. Prior research (Chin \& Chi, 2009; Newton et al., 2013) indicates that loss (LOSS), size (SIZE), leverage (LEVERAGE), market-to-book ratio (MARKET_TO_BOOK), return on assets $(R O A)$, and year and industry dummies should be included in the model. The argumentation for inclusion of size, loss and leverage is the same as in the previous model. The market-to-book ratio is generally higher for restating companies and is therefore included. Return on assets is included to account for any effects profitability may have on audit quality. Again, industry dummies control for differences among industries, and year controls for general changes over time. All control variables are defined in the appendix.

For model (3), based on previous literature (Carey \& Simnett, 2006; DeFond et al., 2002; DeFond \& Zhang, 2014) and adapted to which data is available, size (SIZE), leverage (LEVERAGE), operating cash flows scaled by assets (CFO), an indicator variable for the type of auditor (BIG4), return on assets $(R O A)$ and industry dummies are included again. Size is included because larger companies are less likely to go bankrupt. Leverage is considered to increase the risk of bankruptcy. Poor operating cash flows are generally associated with a higher risk of bankruptcy. The type of auditor indicator controls for the propensity of the auditor to issue a going-concern opinion. Return on assets measures company performance, and thus affects the risk of bankruptcy as well. Industry dummies are included because of the variety of industries found in the sample and their potential differences in financial profiles. Moreover, a new control variable $(P B A N K)$ is included to account for the probability of bankruptcy as measured by an adjusted Zmijewski score. This measure incorporates financial variables found to be significant in bankruptcy prediction studies. Here, the form of the model as used by Carcello, Hermanson and Huss (1995) and Carey and Simnett (2006) is: PBANK = -4.803 - 3.6(net income/total assets) +5.4 (total debt/total assets) - 0.1(current assets/current liabilities). All control variables are defined in the appendix. 
Table 3, panel A reports client-level descriptive statistics of the variables used in the audit quality models for the selected sample. Within this sample, the mean value of AWCA is 4.763 , the mean value of RES is 0.105 , the mean value of OPINION is 0.071 and the mean value of MSI is 0.297. Table 3, panel $B$ reports Pearson correlations for the dependent and control variables. Correlations among the variables are generally low; apart from the expected high correlation of PBANK with LEVERAGE (0.9635), CFO (-0.6209) and ROA (-0.7654) there are only a few correlation values greater than 0.50 . Moreover, multicollinearity is not a problem.

Table 3: Descriptive statistics for client-level variables

\begin{tabular}{lccc}
\hline \multicolumn{2}{l}{ Panel A: Distributional properties of variables } & & Mean \\
\hline Variable & $\mathrm{N}$ & 4.763 & Std. Dev. \\
\hline AWCA & 17,555 & 0.105 & 0.307 \\
RES & 17,555 & 0.522 \\
OPINION & 16,317 & 0.256 \\
MSI & 17,555 & 0.297 & 0.318 \\
LOSS & 17,555 & 0.346 & 0.476 \\
SIZE & 17,555 & 5.955 & 2.508 \\
LEVERAGE & 17,555 & -0.776 & 2.769 \\
SALES_GROWTH & 17,555 & 0.363 & 4.186 \\
CFO & 17,555 & -0.016 & 0.516 \\
BIG4 & 17,555 & 0.680 & 0.466 \\
MARKET_TO_BOOK & 17,555 & 2.859 & 11.451 \\
ROA & 17,555 & -0.187 & 1.689 \\
PBANK & 17,554 & -0.235 & 19.189
\end{tabular}

\footnotetext{
Notes: AWCA is the difference between realized working capital and a proxy for the market's expectations. RES is equal to 1 if a company restated its financial statements in year $t$, and 0 otherwise. OPINION is equal to 1 if a company received a going-concern opinion in year $t$, and 0 otherwise. MSI is the instability of the market share of a company's auditor in year $t$, measured in audit fee income. LOSS is equal to 1 if a company's net income in year $t$ is below zero, and 0 otherwise. SIZE is the log of total assets (in millions). LEVERAGE is a company's total liabilities scaled by total assets. SALES_GROWTH is a company's one-year growth in sales from year $t-1$ to year $t$. CFO is a company's cash flows from operations scaled by total assets in year $t$. BIG4 is equal to 1 if client uses a Big 4 auditor, and 0 otherwise. MARKET_TO_BOOK is the market value of common equity divided by the book value. ROA is a company's revenue scaled by its assets in year $t$. PBANK is the probability of bankruptcy as measured by an adjusted Zmijewski score.
}

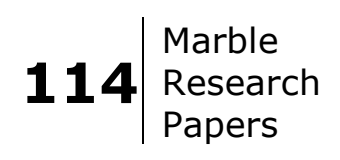




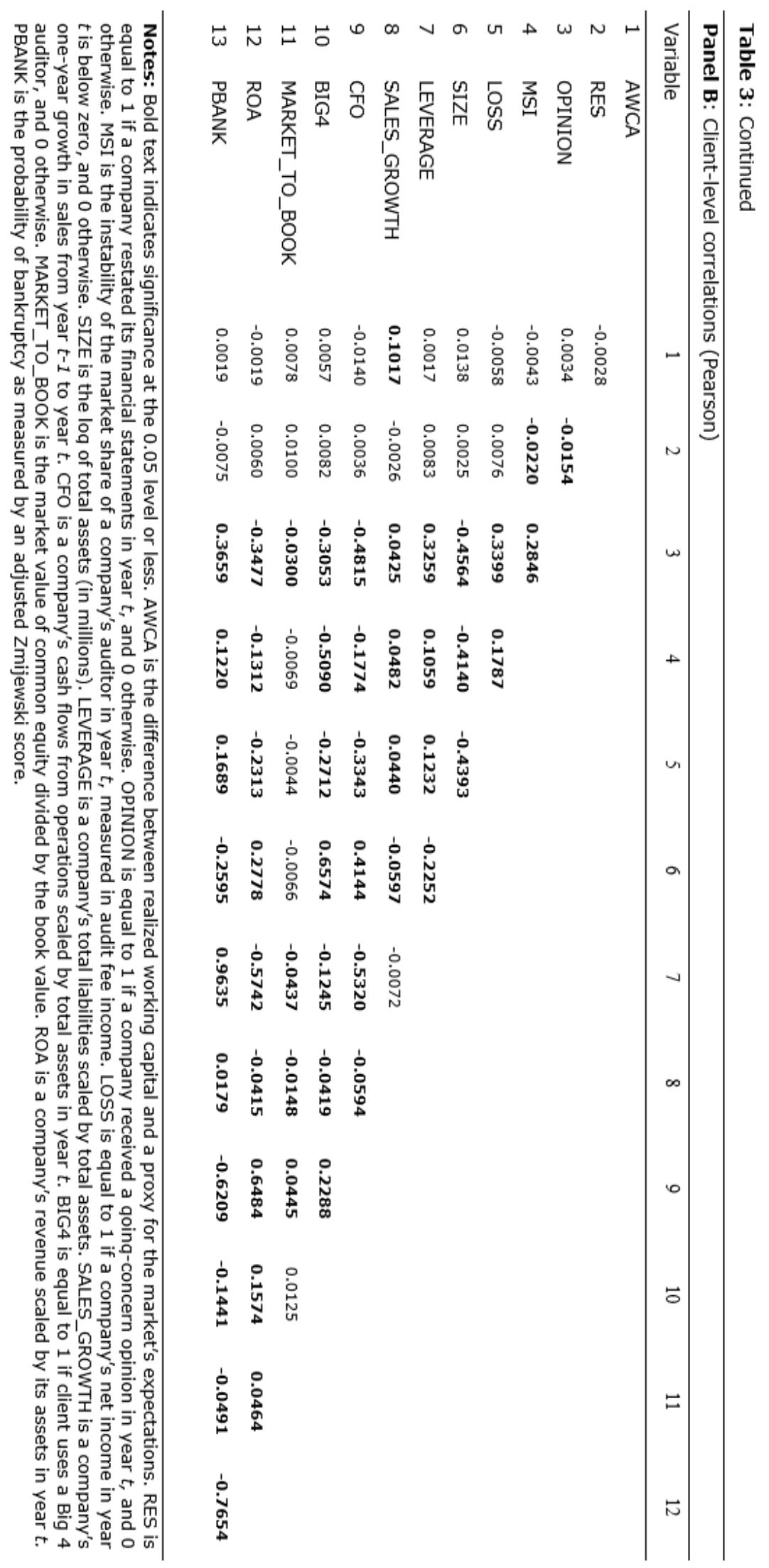




\section{Analysis and results}

Firstly, the market structure dynamics in the U.S. market from 2005 to 2013 will be described and compared to the static market structure. Market share turnover is a static market structure measure, measured as the sum of the change in market share per auditor, divided by two. An overview of the comparison can be found in Figure 1 . As can be observed, the market share instability at the market level has steadily risen from 2005 to 2007, after which a slight drop followed by a steep increase can be noticed. One reason for this increase could be the financial crisis; clients began to question the reliability of their auditors and decided to engage new auditors. Over the last few years, market share instability has been quite stable, but lower than in previous years. Compared to market share turnover (MST), market share instability (MSI) is, as expected, much higher in all years.

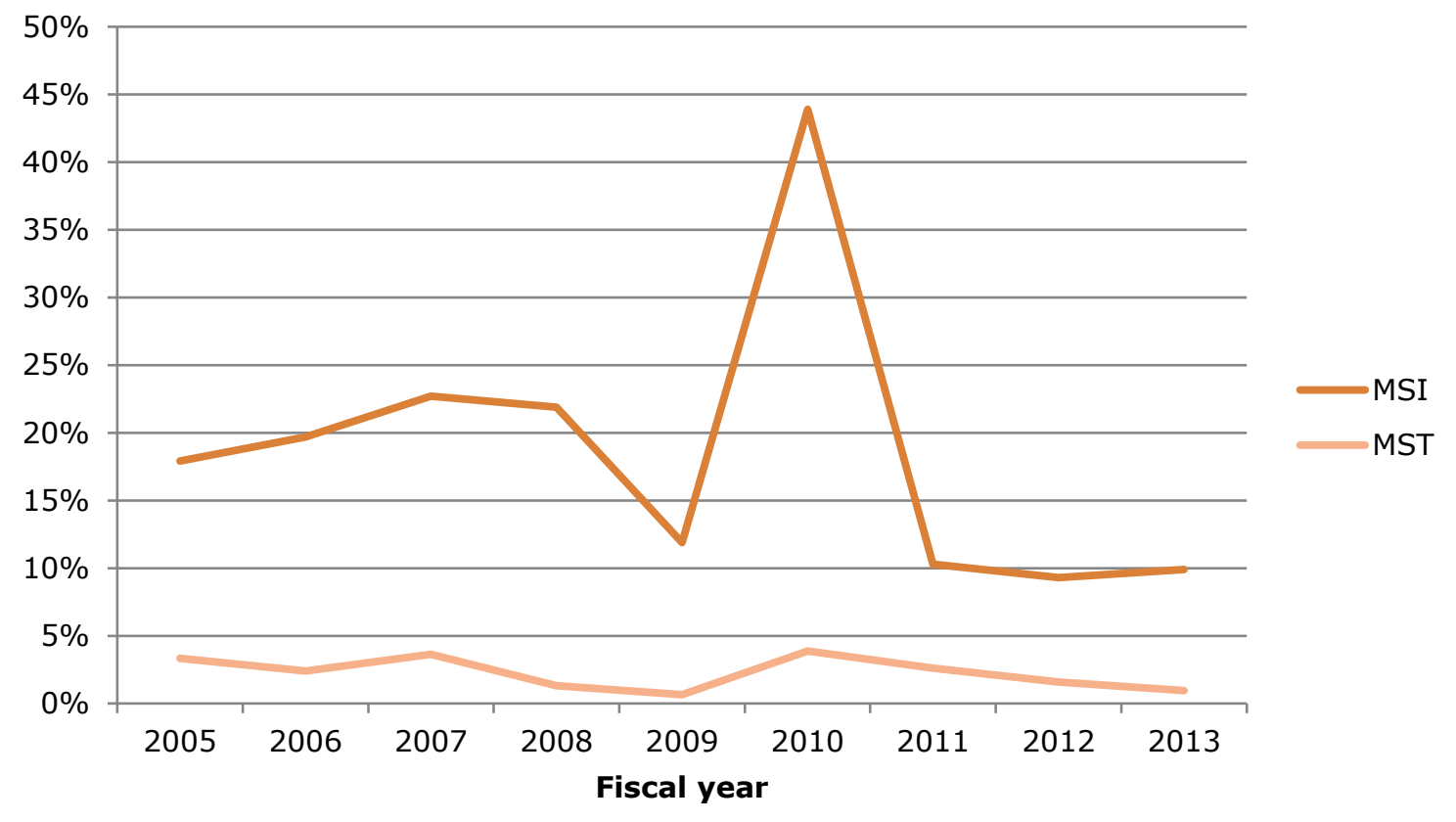

Figure 1: Market Share Instability and Market Share Turnover compared

Secondly, regressions were performed to test the relation of the test variable $M S I$ to audit quality (as proxied for by AWCA, RES and OPINION) in the following three models:

$A W C A=\beta_{0}+\beta_{1} M S I+\beta_{2}$ LOSS $+\beta_{3}$ SIZE $+\beta_{4}$ LEVERAGE $+\beta_{5}$ SALES_GROWTH $+\beta_{6}$ CFO $+\beta_{7}$ BIG4 + Year fixed effects + Industry fixed effects

$R E S=\beta_{0}+\beta_{1} M S I+\beta_{2} L O S S+\beta_{3} S I Z E+\beta_{4}$ LEVERAGE $+\beta_{5}$ MARKET_TO_BOOK $+\beta_{6}$ ROA + Year fixed effects + Industry fixed effects

OPINION $=\beta_{0}+\beta_{1}$ MSI $+\beta_{2}$ PBANK $+\beta_{3}$ SIZE $+\beta_{4}$ LEVERAGE $+\beta_{5}$ CFO $+\beta_{6} B I G 4+\beta_{7}$ ROA Industry fixed effects
$116 \mid \begin{aligned} & \text { Marble } \\ & \text { Research } \\ & \text { Papers }\end{aligned}$ 
All variables are defined in the appendix. Regressions were performed for all dependent variable models. As described in the research design, models (1) and (2) include the full sample size, while model (3) includes fewer observations due to a lack of data about the audit opinions in some client-year observations. Table 4 reports results of the regressions on the selected sample for the three models. All models are significant at $p<0.001$, and the adjusted model R-squares are 1.1, 0.4 and 33.7 percent for the abnormal working capital accruals, restatements and going-concern opinions, respectively. Control variables are generally significant in models (1) and (3), but insignificant in model (2).

Table 4: Regression results

\begin{tabular}{|c|c|c|c|}
\hline \multirow[b]{3}{*}{ Variable } & \multicolumn{3}{|c|}{ Dependent variable } \\
\hline & AWCA & $\underline{\mathrm{RES}}$ & OPINION \\
\hline & Model (1) & Model (2) & Model (3) \\
\hline \multicolumn{4}{|l|}{ Test variable } \\
\hline MSI & -0.326 & $-0.018 * *$ & $0.095 * * *$ \\
\hline \multicolumn{4}{|l|}{ Control variables } \\
\hline LOSS & -4.414 & 0.008 & n.a. \\
\hline SIZE & $3.298 * *$ & -0.001 & $-0.030 * * *$ \\
\hline LEVERAGE & -0.525 & -0.001 & $-0.047 * * *$ \\
\hline SALES_GROWTH & $7.241 * * *$ & n.a. & n.a. \\
\hline CFO & $-13.171 * *$ & n.a. & $-0.149 * * *$ \\
\hline BIG4 & -3.676 & n.a. & $0.013 * * *$ \\
\hline MARKET_TO_BOOK & n.a. & 0.000 & n.a. \\
\hline ROA & n.a. & 0.001 & $0.036 * * *$ \\
\hline PBANK & n.a. & n.a. & $0.010 * * *$ \\
\hline Year fixed effects & YES & YES & NO \\
\hline Industry fixed effects & YES & YES & YES \\
\hline$N$ & 17,555 & 17,555 & 16,317 \\
\hline Model $p$-value & $<0.001$ & $<0.001$ & $<0.001$ \\
\hline Adjusted $R^{2}$ & 0.0111 & 0.0042 & 0.3368 \\
\hline
\end{tabular}

Notes: $* * *, * *$ and $*$ indicate significance at the $0.01,0.05$, and 0.10 level respectively. AWCA is the difference between realized working capital and a proxy for the market's expectations. RES is equal to 1 if a company restated its financial statements in year $t$, and 0 otherwise. OPINION is equal to 1 if a company received a going-concern opinion in year $t$, and 0 otherwise. MSI is the instability of the market share of a company's auditor in year $t$, measured in audit fee income. LOSS is equal to 1 if a company's net income in year $t$ is below zero, and 0 otherwise. SIZE is the log of total assets (in millions). LEVERAGE is a company's total liabilities scaled by total assets. SALES_GROWTH is a company's one-year growth in sales from year $t$ 1 to year $t$. CFO is a company's cash flows from operations scaled by total assets in year $t$. BIG 4 is equal to 1 if client uses a Big 4 auditor, and 0 otherwise. MARKET_TO_BOOK is the market value of common equity divided by the book value. ROA is a company's revenue scaled by its assets in year $t$. PBANK is the probability of bankruptcy as measured by an adjusted Zmijewski score. 
The test variable, MSI, measures the instability of the market share of a company's auditor in year $t$. In model (1), the dependent variable is abnormal working capital accruals (AWCA), and MSI is insignificant at the 10 percent level. In model (2), the dependent variable is restatement (RES), and the coefficient on MSI has a value of -0.018 and is significant at $p<0.05$. The results indicate that restatements are significantly less common for firms that have an auditor with high market share instability. In model (3), the dependent variable is audit opinion (OPINION), and the coefficient of MSI has a value of 0.095 and is significant at $p<0.01$. These results indicate that auditors are significantly more likely to issue a going-concern opinion when they have high market share instability.

When the regressions were performed with a sample that included the previously excluded outliers the results remained unchanged. Moreover, model (3), with OPINION as the dependent variable, was regressed over a sample of clients that made a loss in year $t$ because it has been argued that goingconcern problems are more salient among loss-making firms (Carey \& Simnett, 2006; DeFond et al., 2002). The results for this regression were significant and in the same direction as they were in the analysis of the full sample, although they were stronger in the reduced sample.

As the test variable, MSI, is significant in the expected direction in models (2) and (3), the results of these regressions confirm the hypothesis: there is a positive relationship between audit market dynamics and audit quality. The insignificance of MSI in model (1) indicates that there is no relation between market share instability and abnormal working capital accruals. Thus, with this model in isolation it is impossible to reject the null hypothesis that there is no relation between market share instability and audit quality. Nevertheless, based on all three models in aggregate, the null hypothesis is rejected and the hypothesis stated earlier is confirmed.

\section{Discussion and conclusion}

This research set out to identify the dynamic market structure in the U.S. audit market and to determine the effect of these dynamics on audit quality. Prior research has solely studied static market structures, and has found mixed results regarding the effect of the market structure on audit quality. This study adds value to the existing body of literature by using a more sophisticated measure of competition, market share instability, which accounts for more changes in the market than static measures such as concentration. Firstly, the results of this study show that the U.S. audit market has a higher degree of market share instability than the degree of static market share turnover. Secondly, the results indicate that market share instability has a positive effect on audit quality; the hypothesis is confirmed.

Regarding the results of prior research using static market measures to determine the effects of competition on audit quality, this study confirms the results of studies that conclude that audit quality decreases with decreased competition (e.g. Boone et al., 2012). Moreover, the results of the current study put the results of some prior studies in a different light. Newton et al. (2013), for example, concluded that increased competition in fact decreased audit quality, which contradicts the findings of this study. However, the results found by Newton et al. (2013) might have been different if they had examined dynamic measures of the market structure instead of the static measures, as the static measure used in the study does not fully capture all changes in the market.

Moreover, the results of this research can be compared to the only other study that has attempted to map market share dynamics: Buijink et al. (1998). This study identified market entry and exit in the German and Dutch audit markets from 1970 to 1994, and found a rate of market share

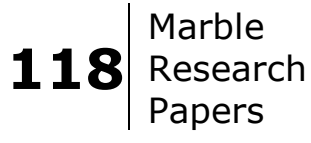


mobility that averaged a little lower than the average market share instability found in this study. The current study, however, used a measure of market share instability that was more explanatory of the market share dynamics than the market share mobility measure that was used by Buijink et al. (1998), as this research accounted for intrafirm changes as well as entries and exits in one variable. Moreover, the prior research concluded that market share mobility was increasing over the years, which may also partly explain the higher rates of instability found in this study. Thus, the results of the study seem to be in line with the expectations based on the prior research by Buijink et al. (1998).

Furthermore, the results provide valuable insights to policymakers regarding the regulation of audit markets, especially in the context of the current global concerns about audit quality due to a believed lack of competition in audit markets. While this study finds that market share instability has decreased in recent years, it also finds that there is in fact high market share instability in the U.S. market, which is inconsistent with a lack of competition. Moreover, this study confirms that audit market competition leads to higher audit quality. Therefore, the results indicate that there should be no reason to be concerned about the decline of audit quality due to a lack of competition, as long as the market share instability remains high. On the other hand, while the study indicates no reason for concern at this time, the results do confirm that regulations such as mandatory audit firm rotation have the potential to increase audit quality, as they increase the dynamic changes in audit markets.

Nevertheless, this study certainly has limitations as well. First, the analysis only covers a limited period of time, but the inclusion of more years would lead to a more reliable and valuable result. In addition, a large amount of client-year observations had to be excluded from the study due to a lack of data. Moreover, while three proxies for audit quality were used, they are still proxies; they cannot completely capture audit quality. Furthermore, this study only covers a sample of the U.S. audit market. This does not necessarily have to be representative of other markets, such as the European or Asian market, and therefore the results cannot be extrapolated into these markets.

Future research could look into audit markets different from the U.S. market to examine the dynamic market structures in multiple countries and compare them. Furthermore, it could be valuable to conduct an analysis for the separate U.S. metropolitan statistical areas to identify differences in the effect of market share instability on audit quality between local markets. Lastly, future research could include a larger timeframe in a similar analysis to produce more relevant results, or to observe whether newly introduced regulation has an effect on the dynamics of the audit market and hence, on the audit quality.

\section{References}

Boone, J.P., Khurana, I.K., \& Raman, K.K. (2012). Audit market concentration and auditor tolerance for earnings management. Contemporary Accounting Research, 29(4), 1171-1203.

Buijink, W.F.J., Maijoor, S.J., \& Meuwissen, R.H.G. (1998). Competition in auditing: Evidence from entry, exit, and market share mobility in Germany versus the Netherlands. Contemporary Accounting Research, 15(3), 385-404.

Carcello, J.V., Hermanson, D.R., \& Huss, H.F. (1995). Temporal changes in bankruptcy-related reporting. Auditing: A Journal of Practice \& Theory, 14(2), 133.

Carey, P., \& Simnett, R. (2006). Audit partner tenure and audit quality. The Accounting Review, 81(3), 653-676. 
Chin, C.L., \& Chi, H.Y. (2009). Reducing restatements with increased industry expertise. Contemporary Accounting Research, 26(3), 729-765.

Ciconte, W., Knechel, W.R., \& Schelleman, C. (2015). An examination of the relation between market structure and the profitability of audit engagements. Accounting \& Finance, 55(3), 749-781.

Davies, S.W., \& Geroski, P.A. (1997). Changes in concentration, turbulence, and the dynamics of market shares. Review of Economics and Statistics, 79(3), 383-391.

DeAngelo, L.E. (1981). Auditor size and audit quality. Journal of Accounting and Economics, 3(3), 183199.

DeFond, M.L., \& Park, C.W. (2001). The reversal of abnormal accruals and the market valuation of earnings surprises. The Accounting Review, 76(3), 375-404.

DeFond, M.L., Raghunandan, K., \& Subramanyam, K.R. (2002). Do non-audit service fees impair auditor independence? Evidence from going concern audit opinions. Journal of Accounting Research, $40(4), 1247-1274$.

DeFond, M.L., \& Zhang, J. (2014). A review of archival auditing research. Journal of Accounting and Economics, 58(2), 275-326.

Eckard, E. (1987). Advertising, competition, and market share instability. Journal of Business, 60(4), 539-552.

European Commission (2016). Fact sheet: Reform of the EU statutory audit market. Brussels: European Commission. Retrieved from http://europa.eu/rapid/pressrelease MEMO-16-2244 en.htm

Farris, P.W., Bendle, N., Pfeifer, P., \& Reibstein, D. (2010). Marketing metrics: The definitive guide to measuring marketing performance. New Jersey: Pearson Education.

Francis, J.R. (2011). A framework for understanding and researching audit quality. Auditing: A Journal of Practice \& Theory, 30(2), 125-152.

Francis, J.R., Michas, P.N., \& Seavey, S.E. (2012). Does audit market concentration harm the quality of audited earnings? Evidence from audit markets in 42 countries. Contemporary Accounting Research, 30(1), 325-355.

International Auditing and Assurance Standards Board (2014). A framework for audit quality: Key elements that create an environment for audit quality, February 2014. New York: IFAC.

Kallapur, S., Sankaraguruswamy, S., \& Zang, Y. (2010). Audit market competition and audit quality. SSRN Working Paper.

Knechel, W.R., Krishnan, G.V., Pevzner, M., Shefchik, L.B., \& Velury, U.K. (2012). Audit quality: Insights from the academic literature. Auditing: A Journal of Practice \& Theory, 32(1), 385-421.

Myers, J.N., Myers, L.A., \& Omer, T.C. (2003). Exploring the term of the auditor-client relationship and the quality of earnings: A case for mandatory auditor rotation? The Accounting Review, 78(3), 779-799.

Newton, N.J., Wang, D., \& Wilkins, M.S. (2013). Does a lack of choice lead to lower quality? Evidence from auditor competition and client restatements. Auditing: A Journal of Practice \& Theory, 32(3), 31-67.

Pepall, L., Richards, D., \& Norman, G. (2008). Industrial organization: Contemporary theory and empirical applications ( $4^{\text {th }}$ ed.). New York: Wiley-Blackwell.

Schmalensee, R.D. (1989). Inter-industry studies of structure and performance. In R.D. Schmalensee \& R.D. Willig (Eds.), Handbook of industrial organization (pp. 951-1009). Amsterdam: Elsevier Publishers.

$120 \mid \begin{aligned} & \text { Marble } \\ & \text { Research } \\ & \text { Papers }\end{aligned}$ 
Sandler, R.D. (1988). Market share instability in commercial airline markets and the impact of deregulation. The Journal of Industrial Economics, 36(3), 327-335.

Tirole, J. (1988). The theory of industrial organization. Boston: MIT Press.

United States Treasury (2008). Advisory committee on the auditing profession: Final report.

Retrieved from: http://www.treas.gov/about/organizational-structure/offices/ Documents/finalreport.pdf

Appendix: Definition of variables

\begin{tabular}{|c|c|}
\hline Variable & Definition \\
\hline \multicolumn{2}{|l|}{ Dependent variables } \\
\hline AWCA & $\begin{array}{l}\text { The difference between realized working capital and a proxy for the } \\
\text { market's expectations }\end{array}$ \\
\hline RES & $=1$ if the company made a restatement in year $t$, and 0 otherwise \\
\hline OPINION & $\begin{array}{l}=1 \text { if the company received a going-concern opinion in year } t \text {, and } \\
0 \text { otherwise }\end{array}$ \\
\hline \multicolumn{2}{|l|}{ Test variables } \\
\hline MSI & $\begin{array}{l}\text { The instability of the market share of a company's auditor in year } t \text {, } \\
\text { calculated by adding audit fee income from the clients engaged to } \\
\text { and departed from an auditor in year } t \text {, and dividing that by the } \\
\text { total clients an auditor has in year } t \text {. }\end{array}$ \\
\hline \multicolumn{2}{|l|}{ Control variables } \\
\hline LOSS & $=1$ if net income in year $t$ is below zero, and 0 otherwise \\
\hline SIZE & Log of total assets (in millions) in year $t$ \\
\hline LEVERAGE & A company's total liabilities scaled by total assets in year $t$ \\
\hline SALES_GROWTH & A company's one-year growth in sales from year $t-1$ to year $t$ \\
\hline CFO & $\begin{array}{l}\text { A company's cash flows from operations scaled by total assets in } \\
\text { year } t\end{array}$ \\
\hline BIG4 & $=1$ if client uses a Big 4 auditor, and 0 otherwise \\
\hline MARKET_TO_BOOK & Market value of common equity divided by the book value \\
\hline ROA & A company's revenue scaled by its assets in year $t$ \\
\hline PBANK & $\begin{array}{l}\text { Probability of bankruptcy as measured by an adjusted Zmijewski } \\
\text { score }\end{array}$ \\
\hline
\end{tabular}

Audit Market 